\title{
FACTORS AFFECTING THE UTILIZATION OF ANTENATAL CARE SERVICES IN IBADAN, NIGERIA
}

\author{
* M.D Dairo, **K.E. Owoyokun

\section{Correspondence:} \\ ${ }^{\star}$ Dr. Dairo M.D \\ Department of Epidemiology \& Medical Statistics, \\ College of Medicine, \\ UCH, Ibadan. \\ Email: drdairo@yahoo.com,
}

*Department of Epidemiology \& Medical Statistics, College of Medicine, UCH, Ibadan. Email: drdairo@yahoo.com, ** Department of Epidemiology \& Medical Statistics, College of Medicine, UCH, Ibadan. Email: ebenkunle@yahoo.com

\section{ABSTRACT}

BACKGROUND: Antenatal care utilization is still low in Nigeria. This underutilization varies from region to region and from state to state. This study assesses the factors that determine the utilization of antenatal care service in Ibadan.

METHODS: A cross-sectional study was carried out in two randomly selected local government council area in Ibadan. A pretested questionnaire was administered to 400 women. Information was obtained from the women on their attendance at antenatal clinic and the reasons for not attending the antenatal clinics

RESULTS: Majority (76.8\%) of the respondents attended ANC clinic. Women in urban areas were more than 2 times likely to attend antenatal clinic than women in urban areas [(OR=2.177, 95\% Cl, 1.081-4.382)]. Women who were Muslims or other religions were more than 2 times likely to attend ANC clinic than women who were Christians [(OR=2.398, 95\% Cl, 1.264-4.557)]. Also, Women who were 25 years and older were more than 2 times more likely to utilize antenatal than women who were 25 years or younger $[(\mathrm{OR}=2.236,95 \% \mathrm{Cl}, 1.106$ 4.107].

CONCLUSION: Efforts towards ensuring the utilization should be targeted towards rural areas, the importance of modern antenatal care should be emphasized even in the religious settings and younger women should be encouraged to utilize antenatal care services.

Key words: maternal health services, antenatal care, utilization

\section{INTRODUCTION}

Women of reproductive age has been defined according to $\mathrm{WHO}$ as those between 15-49, and these constitute more than one fifth of the world $\hat{\Phi}$ population and are repeatedly exposed to the risk of pregnancy and child bearing. Maternal health refers to the health of the mother during pregnancy, childbirth and the postpartum period ${ }^{1}$. Maternal health care services utilization is important for early detection of mothers who are at high of illness and mortality during pregnancy ${ }^{2}$. Maternal health services usually are preventive and the patients are not usually ill. It is therefore easy 
for the services to be underused ${ }^{3}$. In the developing countries, these problems are even more prevalent due to the current socioeconomic conditions and inaccessibility of health facilities ${ }^{4}$. The utilization of maternal health service definitely is essential strategy in reducing the risks associated with pregnancy and child bearing in this age group ${ }^{1}$. The essential maternal health care services during pregnancy included antenatal care, skilled care at delivery and postpartum care and these are necessary to promote good health.

Antenatal care is the care received during pregnancy from skilled health personnel such as the goal oriented model recommended by the WHO which include 4-5 visits for pregnant women who are not having medical problems ${ }^{5}$. Antenatal care utilization $(65 \%)$ in the developing countries is low when compared to that of the developed countries which is $97 \%$. Skilled attendance at delivery is 53\% in developing countries while it is $99 \%$ in the developed countries and postpartum care utilization is $30 \%$ compared to $90 \%$ in developed countries $^{5}$. In Nigeria antenatal care utilization is reported to be $63 \%{ }^{6}$.

The wide disparity in maternal health care indicators might explain the wide difference in maternal mortality ratio between the developed and developing countries ${ }^{1}$. Of the 210 million women who become pregnant each year, 30 million or about $15 \%$ develop complications which are fatal in $1.7 \%$ up cases ${ }^{1}$.

It has also been a challenge to assess the extent of progress towards the MDG 5 target of improving maternal health; due to lack of reliable data especially in developing countries ${ }^{7}$. There is a dearth of recent data on the influences of antenatal care use in Ibadan, Southwestern
Nigeria. This study therefore assesses the factors that determine the utilization of antenatal health care service in lbadan.

\section{MATERIALS AND METHODS}

Study Area: The study areas were two selected local government areas in Ibadan. Ibadan is the capital of Oyo State, the third largest city in Nigeria by population (after Lagos and Kano) and the largest in geographical area. It is located in south-western Nigeria. It has population is $2,550,593$. Ibadan is made up of 11 Local government areas. Each local government is divided into health districts and each health district has one health centre. The local government areas in Ibadan are categorized into as rural and urban based on the Smelser $\hat{\boldsymbol{s}}$ criteria $^{9}$. The randomly selected urban local government area is lbadan North. The rural local government area selected is Egbeda.

Study Population: The study population consisted of women who brought the baby born at last delivery to the primary health care centres for immunization and other health services.

Study Design: The study was crosssectional in design

The sampling procedure: $A$ two stage multistage sampling technique was used to obtain representative sample of health facilities and women as follows

Stage 1: sampling the local
government areas: stratified random sampling: A sampling frame of all local government areas in the state was drawn and stratified into urban and rural local government areas. A representative sample of one 
urban and one rural local government areas was then obtained by sample random sampling.

\section{Stage 2: sampling the health} centres: simple random sampling:

A sampling frame of all the health centres in the selected local government areas was drawn. Three primary health care centre, were randomly selected in the rural local government area and 2 was selected in the urban local government area.

Data Collection: The women were interviewed to study the pattern of utilization of antenatal, delivery and postnatal care services in their last deliveries using pre-tested semi structured questionnaires. The questionnaire was translated to Yoruba and it collected information on socio demographic variables including age, religion, occupation, educational level, average monthly income and marital status. Information on the patientsô use of modern antenatal services during the past delivery was also collected.

Data Analysis: Data was analyzed using SPSS version 15. Descriptive summary statistics such as mean and standard deviation were computed for continuous variables and proportions for categorical characteristics of the women. Test of association was carried out using the chi-square test. Multivariate logistic regression was performed to identify significant predictors, all at $5 \%$ level of significance.

\section{RESULTS}

Socio-demographic characteristics of the study population: 400 women were interviewed and their sociodemographic characteristics are shown in table 4.1. The mean age (standard deviation) of the respondents was 27.8(5.6) years. Majority $(93.2 \%)$ of the respondents were Yoruba (93.2), Christians (63, $0 \%)$, and married (93.0\%). Most (40.5 $\%)$ of the mothers were young with a modal age of were aged 25-29 years. Majority $(55.8 \%)$ had secondary education. A significant percentage $(39.3 \%)$ were primipara while $243(60.8 \%)$ had at least one child before their last pregnancy.

\section{Venue of antenatal clinic attendance} and reasons for not attending: Of the 400 respondents interviewed, 92(23.69\%) sought traditional antenatal care while $24(6 \%)$ neither sought modern nor traditional antenatal care. 307(76.8\%) attended ANC clinic at least once during their last pregnancy. Of these, 86(28.0\%) attended a private hospital for their ANC clinic, $75(24.4 \%)$ attended a PHC centre, 48(15.6\%) attended a state specialist hospital, 43(14.0\%) attended a general hospital,27(8.8\%) attended a maternity home,26(8.5\%) attended a teaching hospital and 2(0.7\%) attended a missionary hospital for their antenatal care.(Table 4.2). Respondents who neither sought modern nor traditional antenatal care during pregnancy gave various reasons for not seeking ANC care at all. Fourteen $(58.3 \%)$ gave the inability to afford cost of antenatal care as the reason for not obtaining antenatal care at all. The other reasons reported by the women who did not seek antenatal care at all includde the attitude of care givers $(14.8 \%)$, the long time that will be spent in obtaining antenatal care $8(29.6 \%)$, did not think antenatal care was even important 16(59.39\%), distance to venue of antenatal care $6(22.2 \%)$, religious reasons $1(3.7 \%)$ while others claimed they had no chance to attend $8(29.6 \%)$. (Table 4.3 ) 
The mean gestational age at booking was $21.4 \pm 4.6$ weeks and the mean number of ANC visits was $9.07 \pm 5.89$ visits.

Services received at ANC Clinic: The services received by the respondents at the antenatal clinic is shown in table 3.0. The women got screened for risk factors, TT vaccinations, given IPT, given ITN and health advice. The most common service rendered to the women at the ANC clinic was weight measurement $301(98 \%)$. The receipt of deworming tablets 197(64.2\%) was the lowest(4.5). The women were also given health education with the information received on diet $298(97.1 \%)$ highest, while the information received on HIV/AIDS was at $261(85.0 \%$ ) (Table 3$)$.

Determinants of modern ANC care utilization: On bivariate analysis, age showed a significant association with use of modern ANC care. Women who were 25 years or more [245(79.0\%)] were more likely to attend ANC clinic than women who were less than 25 years $62(68.9 \%)$. Tribe also showed a significant association with seeking modern antenatal care with more Yoruba women [293 (78.8\%)] attending ANC clinic compared to other tribes [14(51.9\%), $\quad P<0.01]$. Christians [185(73.4\%)] were less likely to attend ANC clinic compared to other religions [122(82.4\%), $\mathrm{P}<0.05]$. Married women [291(78.2\%)] were more likely to attend ANC clinic compared to women who were single, separated or divorced [16(57.1\%)]. Educational status also showed a significant association with respondents having an education of secondary school and above [275(82.1\%)] attending ANC clinic more compared to women who had an education of primary school and below
[32(50.0\%), $P<0.01]$. The respondentsô

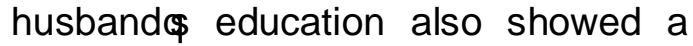
significant association with those whose husband had an education of secondary school and above [294(79.0\%)] attending ANC clinic more compared to respondents whose husband had an education of secondary school education [13(46.4\%), $\quad p<0.001]$. Professionals [98(91.6\%)] were most likely to attend ANC clinic when compared to skilled respondents $110 \quad(77.5 \%)$ and the unskilled or unemployed [79(65.8\%), $\mathrm{p}<0.001]$. The respondentsô husband occupational status also showed significance as the respondents whose husbands were professionals (lower, middle and higher) [176(46.9\%)] were most likely to attend ANC clinic compared to those whose husband were skilled [113(30.1\%)] and unskilled [80 (21.3\%), $\quad p<0.001]$. Respondents located in urban areas [174(87.0\%)] were more likely to attend ANC clinic than those in the rural area [133(66.5\%), $p<0.001]$. Also, Respondents who participate in taking health decisions either alone or jointly with their husbands were more likely to use ANC [228(78.9)] than respondents whose husband or someone else take the decision concerning the respondent $\hat{\Phi} \quad$ health [79(71.2), $\mathrm{P}<0.05]$.

The income of the respondents and the income of the respondentsô husband, the family type and the number of children born before the last pregnancy did not show a significant association on bivariate analysis (Table 4.6). All variables which showed a significant association with the utilization of ANC clinic in the bivariate analysis were put in a multiple logistic regression model to assess the effects of individual variables on ANC clinic attendance during last pregnancy. 
Multivariate analysis: After adjusting for other factors, women in urban areas were more than 2 times likely to attend antenatal clinic than women in urban areas $[(\mathrm{OR}=2.177,95 \% \mathrm{Cl}$, 1.081-4.382)]. Women who were Muslims or other religions were more than 2 times likely to attend ANC clinic than women who were Christians [(OR=2.398, 95\% Cl, 1.264-4.557). Women who were 25 years and older were more than 2 times more likely to utilize antenatal than women who were 25 years or younger [ $(\mathrm{OR}=2.236,95 \%$ $\mathrm{Cl}, 1.106-4.107]$.

\section{DISCUSSION}

The study examined the use of maternal health care services in lbadan, Southwestern Nigeria. The utilization of antenatal care services was generally high(76.8\%) , this proportion is higher than the proportion reported in the Nigerian demographic health survey, 2003 which reported $66.6 \%$ but slightly lower than the proportion reported in a study carried out in Kenya by Anna M van Eijk et al. in Kenya which found that $90 \%$ of women attended antenatal care at least once ${ }^{(3,7) \text {. }}$

Women who were 25 years or more were more likely to attend ANC clinic more than women who were less than 25 years. The findings of our study agrees with a study of 15 developing countries which found that younger women were less likely to use antenatal care service ${ }^{(10)}$ and another study carried out in Peru were older women were found to be more likely to use antenatal care service ${ }^{(11)}$. The authors went further to suggest that this may have been due the older women having more knowledge and placing more value on modern health care. (11). In our study, most of the respondents that did not use antenatal care service were single and reported not being part of decision making on matters that concern their health, a probable lack of support and inability to determine matters concerning their health might explain their limited use of antenatal care service.

Location also appears to have effect on the use of antenatal care. This result is similar to the findings of study by Mansur et al. in Bangladesh which reported women based in urban areas used antenatal care services than those based in the rural areas ${ }^{12}$; a retrospective observational study between 1992 and 2001 in Australia ${ }^{13}$ and nationally representative population based sample survey in India $^{11}$ also reported a higher use of ANC services among respondents based in urban areas than rural areas. This is probably due to the fact that women in urban areas are better informed and the urban women have limited access to ANC services as they have to depend on the primary health care centre for maternal health care services. Thus, women based in urban areas have a lot of options to choose from.

Christians were significantly less likely to attend ANC clinic. A survey of 452 randomly selected pregnant women accessing antenatal care at the primary healthcare facilities in Sagamu Local Government Area (LGA) of Ogun State, southwest Nigeria found that Muslims utilized ANC than other religions. The influence of religion on the use of ANC found in this study agrees with the findings of our study This is probably because most Christians attend spiritual houses for care during pregnancy as most Christian organizations have spiritual houses that offer care for women especially their members.

The lack of influence of education on the use of ANC service in our study 
contrast to other studies on the use of ANC, a study to evaluate the utilisation of antenatal care at the Provincial Specialist Hospital, Mongomo, Guinea Equatoria found higher levels of education generally improved ANC attendance $^{14}$; Saseendran Pallikadavath et al. in a study carried out in Bangladesh also found women with a secondary school education or more were more likely to attend ANC than women with primary school education or less. women with higher levels of education attending ANC during pregnancy ${ }^{11}$.The authors explained that this may be due to more educated women with higher awareness of the importance of antenatal care ${ }^{14}$ The lack of influence of education in our study might be might be due to the fact that there is similar level of awareness on the importance of antenatal care across the different levels of education in Ibadan.

In this study the participation of women in taking decisions concerning their health did not have a significant effect on the use of antenatal care service. This finding is consistent with other studies that have examined the influence of women's autonomy on various health outcomes. A study which used data from a maternal health study carried out in the slums of Nairobi, Kenya found no significant effect of women's participation in decision making concerning their health on the utilization of maternal health services ${ }^{15}$; a study in Nepal also found that the influences of women's involvement in decision-making regarding their own health or large purchases on antenatal care attendance were rather weak $^{16}$. However, Bloom et al found a conflicting result on the influence of women⿳亠丷厂 participation in making decisions about their health when their findings demonstrated that women's autonomy was a major determinant of maternal health care utilization among urban poor to middle-income women in a North Indian city ${ }^{17}$.
Studies involving a larger number of respondents should be carried out to assess the role of woments participation in taking decisions concerning their health affects the use of maternal health services.

\section{REFERENCES}

1. AbouZahr C, Wardlaw T. 2004 Maternal mortality in 2000:estimates by WHO, UNICEF and UNFPA.Geneva: 2001.

2. Maternal Mortality in 2005: Estimates Developed by WHO, UNICEF, UNFPA and the World bank.Geneva, Switzerland: World Health Organization,2007

3. Anna M van Eijk Hanneke M Bless, Frank Odhiambo, Jhon G Ayisi, Ilse E. Blokland, Daniel $H$ Rosen, Kubaje Adazu, Laurent Slutkser and Kim A Lindblade, 6 April, 200. Use of antenatal services and delivery care among women in rural western Kenya: a community based survey: Reproductive Health, 3:2

4. Royston ,E., \& Armstrong, S.(1989). Preventing maternal deaths. The role of maternal health services. WHO Geneva: (pp 153183)

5. Maternal Mortality in 2005: Estimates: World Health Organization, 2007.

6. Stewart MK, Cynthia K, Omar A. 1997.Maternal Health Care. DHS Comparative Studies No. 25. Calverton, Maryland: Macro Internation Inc.

7. Nigeria Demographic and Health Survey 2003. Calverton: National Population Commission and ORC Macro. 
8. Jimoh AA. Utilisation of antenatal services at the Provincial Hospital, Mongomo, Guinea Equatoria. Afr J Reprod Health 2003;7:49-54.

9. Smelser, 1983. Sociology, An Introductory text Blackwell Publishers 1983

10. Heidi W. Reynolds, Emelita L. Wong and Heidi Tucker. Adolescents' Use of Maternal and Child Health Services in Developing Countries International Family Planning Perspectives. Volume 32, Number 1, March 2006

11. Saseendran Pallikadavath, Mary Foss RM and R William Stones Antenatal Care in Rural Madhya Pradesh: Povision and Inequality. Population Resource Centre, Madhya Pradesh 2007-05-16.

12. Md. Mosiur Rahman, Md. Rafiqul Islam and Ahmed Zohirul Isla. Rural-Urban differentials of utilization of ante-natal health care services in Bangladesh Health policy and development Volume 6 number 3 december 2008

13. Olufemi T. Oladapo and Modinat O. Osiberu. Do Sociodemographic Characteristics of Pregnant Women Determine their Perception of
Antenatal Care Quality? Maternal and Child Health Journal Publisher Springer Netherlands ISSN10927875 Volume 13, Number 4 / July, 2009 Pages505-511.

14. AA Jimoh Utilisation of Antenatal Services at the Provincial Hospital, Mongomo, Guinea Equatoria African Journal of Reproductive Health, Vol. 7, No. 3, December, 2003, pp. 49-54

15. Jean-Christophe Fotso, Alex C Ezeh and Hildah Essendi, Maternal health in resource-poor urban settings: how does women's autonomy influence the utilization of obstetric care services? Reproductive Health 2009, 6:9

16. Furuta M, Salway S: Women's position within the household as a determinant of maternal health care use in Nepal. International Family Planning Perspectives 2006, 32(1):17-27.

17. Bloom SS, Wypij D, Gupta M: Dimensions of women's autonomy and the influence on Maternal Health Care Utilization in a North Indian City. Demography 2001, 38(1):67-78 
Table 1: Characteristics of the respondents

\begin{tabular}{|l|r|r|}
\hline \multicolumn{1}{|c|}{ Variables } & Frequency & Percentage \\
\hline Age & & \\
Ò19 & 19 & 4.8 \\
\hline $20-24$ & 71 & 17.8 \\
\hline $25-29$ & 162 & 40.5 \\
\hline $0-34$ & 95 & 23.8 \\
\hline Ó35 & 53 & 13.3 \\
\hline Tribe & & \\
\hline Yoruba & 372 & 93.2 \\
\hline Igbo & 12 & 3.0 \\
\hline Hausa & 4 & 1.0 \\
\hline Others & 11 & 2.8 \\
\hline
\end{tabular}

\section{Religion}

Christianity

252

Islam

146

63.0

Others

2

36.5

0.5

\section{Educational status}

None

Primary

Secondary

12.3

Tertiary

112

55.8

28.0

\section{Occupation}

Professionals

Skilled

26.8

Unskilled

120

35.5

Unemployed

31

30.0

7.7

\section{Husband's Educational status}

None

176

Primary

113

Secondary

Tertiary

80

44.0

28.3

20.0

6

1.5

\section{Husband's occupational status}

Professionals

Skilled

30.1

Unskilled 
Table 2: Venue of antenatal clinic attendance and reasons for not attending ANC

\begin{tabular}{|l|c|c|}
\hline \multicolumn{1}{c|}{ Venue of ANC attendance } & Frequency & Proportion \\
\cline { 2 - 3 } Private hospital & 86 & 28.0 \\
\hline Primary health care centre & 75 & 24.4 \\
\hline State specialist hospital & 48 & 15.6 \\
General hospital & 43 & 14.0 \\
Maternity home & 27 & 8.8 \\
\hline Teaching hospital & 26 & 8.5 \\
Missionary hospital & 2 & 0.7 \\
\hline Reasons for attending antenatal Clinic & & \\
$\quad$ Not financially affordable & 14 & 58.3 \\
$\quad$ Bad attitude of care givers & 4 & 14.48 \\
$\quad$ Long waiting time & 16 & 59.3 \\
$\quad$ Long distance & 8 & 29.6 \\
$\quad$ Religious reasons & 1 & 3.7 \\
$\quad$ Non-availability of antenatal care services & 8 & 29.6 \\
\hline
\end{tabular}

Table 3: $\quad$ Services Received at ANC Clinic

\begin{tabular}{|l|l|l|}
\hline & Frequency & Proportion (\%) \\
\hline Services received at ANC clinic & & \\
$\quad$ Height measurement & 263 & 85.7 \\
\hline Blood pressure & 300 & 97.7 \\
\hline Weight measurement & 301 & 98 \\
Haemoglobin & 247 & 80.7 \\
\hline Iron tablet & 253 & 80.7 \\
Tetanus toxoid injection & 283 & 92.2 \\
Deworming tablet & 197 & 64.2 \\
IPT (antimalaria) & 217 & 70.7 \\
\hline ITN (Insecticide treated net) & 246 & 80.1 \\
\hline Information given at ANC clinic & & \\
Nutrition in pregnancy & 298 & 97.1 \\
Care of the baby & 291 & 94.4 \\
\hline Family planning & 278 & 90.6 \\
Best place of delivery & 284 & 92.5 \\
Progress of Pregnancy & 289 & 94.1 \\
Complications in Pregnancy & 275 & 89.6 \\
What to do during complications & 266 & 86.6 \\
Counselling on HIV/AIDS & 261 & 85.0 \\
\hline
\end{tabular}


Table 4: $\quad$ Bivariate analysis of the determinants of ANC utilization

\begin{tabular}{|c|c|c|c|c|}
\hline Characteristics & ANC(Yes) & ANC(No) & $\mathrm{X}^{2}$ & $P$ value \\
\hline 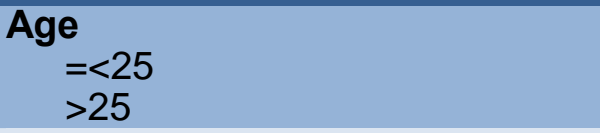 & $\begin{array}{l}68.9(62) \\
79.0(245)\end{array}$ & $\begin{array}{l}31.1(28) \\
21.0(65)\end{array}$ & 4.022 & 0.045 \\
\hline $\begin{array}{l}\text { Tribe } \\
\text { Yoruba } \\
\text { Others }\end{array}$ & $\begin{array}{l}78.8(293) \\
48.1(13)\end{array}$ & $\begin{array}{l}21.2(79) \\
51.9(14)\end{array}$ & 13.199 & 0.001 \\
\hline $\begin{array}{l}\text { Religion } \\
\text { Christians } \\
\text { Non Christians }\end{array}$ & $\begin{array}{l}73.4(185) \\
82.4(122)\end{array}$ & $\begin{array}{l}26.6(67) \\
17.6(26)\end{array}$ & 4.251 & 0.039 \\
\hline $\begin{array}{l}\text { Marital Status } \\
\text { Married } \\
\text { Not Married }\end{array}$ & $\begin{array}{l}78.2(291) \\
57.1(16)\end{array}$ & $\begin{array}{l}21.8(81) \\
42.9(12)\end{array}$ & 6.486 & 0.011 \\
\hline $\begin{array}{l}\text { Family Type } \\
\text { Monogamy } \\
\text { Polygamy }\end{array}$ & $\begin{array}{l}77.6(260) \\
77.5(31)\end{array}$ & $\begin{array}{l}22.4(75) \\
22.5(9)\end{array}$ & 0.001 & 0.987 \\
\hline $\begin{array}{l}\text { Location } \\
\text { Rural } \\
\text { Urban }\end{array}$ & $\begin{array}{l}66.5(133) \\
87.0(174)\end{array}$ & $\begin{array}{l}33.5(67) \\
13.0(26)\end{array}$ & 23.551 & 0.0001 \\
\hline $\begin{array}{l}\text { Educational Status } \\
\text { Primary school and below } \\
\text { Secondary school and above }\end{array}$ & $\begin{array}{l}50.0(32) \\
82.1(275)\end{array}$ & $\begin{array}{l}50.0(32) \\
17.9(60)\end{array}$ & 31.189 & 0.001 \\
\hline $\begin{array}{l}\text { Occupational Status } \\
\text { Unemployed } \\
\text { Unskilled } \\
\text { Skilled } \\
\text { Professionals }\end{array}$ & $\begin{array}{l}64.5(20) \\
65.8(79) \\
77.5(110) \\
91.6(98)\end{array}$ & $\begin{array}{l}35.5(11) \\
34.2(41) \\
22.5(32) \\
8.4(9)\end{array}$ & 23.858 & 0.001 \\
\hline $\begin{array}{l}\text { Husband's Educational Status } \\
\text { Primary school and below } \\
\text { Secondary school and above }\end{array}$ & $\begin{array}{l}46.4(13) \\
80.8(278)\end{array}$ & $\begin{array}{l}53.6(15) \\
19.2(66)\end{array}$ & 17.973 & 0.001 \\
\hline $\begin{array}{l}\text { Husband's Occupational Status } \\
\text { Unemployed } \\
\text { Unskilled } \\
\text { Skilled } \\
\text { Professionals }\end{array}$ & $\begin{array}{l}83.3(5) \\
87.5(70) \\
96.5(109) \\
97.2(171)\end{array}$ & $\begin{array}{l}16.7(1) \\
12.5(10) \\
3.5(4) \\
2.8(5)\end{array}$ & 23.048 & 0.001 \\
\hline $\begin{array}{l}\text { Parity } \\
\text { Primipara } \\
\text { Bipara } \\
\text { Multipara }\end{array}$ & $\begin{array}{l}79.6(125) \\
76.0(79) \\
74.1(103)\end{array}$ & $\begin{array}{l}20.4(32) \\
24.0(25) \\
25.9(36)\end{array}$ & 1.307 & 0.520 \\
\hline $\begin{array}{l}\text { Health Decision } \\
\text { Self only/Jointly with husband } \\
\text { Husband only/Someone else }\end{array}$ & $\begin{array}{l}78.9(228) \\
71.2(79)\end{array}$ & $\begin{array}{l}21.1(61) \\
28.8(32)\end{array}$ & 2.680 & 0.014 \\
\hline
\end{tabular}


Table 5: $\quad$ Multivariate analysis of factors affecting antenatal care utilization

\begin{tabular}{|c|c|c|c|}
\hline Variables & $\operatorname{Exp} \beta=O R$ & C.I & $P$ value \\
\hline $\begin{array}{l}\text { Age } \\
\qquad \begin{array}{l}=<25 \\
\quad>25\end{array}\end{array}$ & $\begin{array}{l}1.0 \\
2.236\end{array}$ & $1.160-4.107$ & 0.015 \\
\hline $\begin{array}{l}\text { Tribe } \\
\text { Others } \\
\text { Yoruba }\end{array}$ & $\begin{array}{l}1.0 \\
1.3799\end{array}$ & $0.470-4.044$ & 0.559 \\
\hline $\begin{array}{l}\text { Religion } \\
\text { Christians } \\
\text { Non Christians }\end{array}$ & $\begin{array}{l}1.0 \\
2.316\end{array}$ & $1.249-4.291$ & 0.008 \\
\hline $\begin{array}{l}\text { Marital status } \\
\text { Not married } \\
\text { Married }\end{array}$ & $\begin{array}{l}1.0 \\
0.364\end{array}$ & $0.025-5.372$ & 0.462 \\
\hline $\begin{array}{l}\text { Location } \\
\text { Rural } \\
\text { Urban }\end{array}$ & $\begin{array}{l}1.0 \\
2.074\end{array}$ & $1.066-4.034$ & 0.032 \\
\hline $\begin{array}{l}\text { Educational status } \\
\text { Primary school and below } \\
\text { Secondary school and above }\end{array}$ & $\begin{array}{l}1.0 \\
1.846\end{array}$ & $0.845-4.033$ & 0.124 \\
\hline $\begin{array}{l}\text { Occupational status } \\
\text { Unemployed } \\
\text { Unskilled } \\
\text { Skilled } \\
\text { Professionals }\end{array}$ & $\begin{array}{l}1.0 \\
1.041 \\
0.432 \\
0.463\end{array}$ & $\begin{array}{l}0.243-4.445 \\
0.122-1.525 \\
0.138-1.557\end{array}$ & $\begin{array}{l}0.956 \\
0.192 \\
0.213\end{array}$ \\
\hline $\begin{array}{l}\text { Husband's educational status } \\
\text { Primary school and below } \\
\text { Secondary school and above }\end{array}$ & $\begin{array}{l}1.0 \\
2.441\end{array}$ & $0.878-6.622$ & 0.08 \\
\hline $\begin{array}{l}\text { Husband's occupational status } \\
\text { Unemployed } \\
\text { Unskilled } \\
\text { Skilled } \\
\text { Professionals }\end{array}$ & $\begin{array}{l}1.0 \\
3.552 \\
4.796 \\
2.383\end{array}$ & $\begin{array}{l}0.552-22.870 \\
0.752-30.577 \\
0.366-15.499\end{array}$ & $\begin{array}{l}0.182 \\
0.097 \\
0.363\end{array}$ \\
\hline $\begin{array}{l}\text { Health decision } \\
\text { Husband only/someone else } \\
\text { Self only/jointly with husband }\end{array}$ & $\begin{array}{l}1.0 \\
1.497\end{array}$ & $0.369-1.211$ & 0.184 \\
\hline
\end{tabular}

